\title{
Exploring the word formation process on Rich Brian's official music video comments
}

\author{
Syifa Dwi Mutiah, Didin Nuruddin Hidayat*, Alek Alek \\ Department of English Education, Faculty of Educational Science, \\ UIN Syarif Hidayatullah Jakarta, Indonesia
}

*Corresponding author

Email: didin.nuruddin@uinjkt.ac.id

Received:

25 December 2020
Revised:

12 February 2021
Accepted:

27 February 2021
Published:

28 February 2021

\begin{abstract}
This study attempted to explore the process of word formation and its social function of slang words on Rich Brian's official music video, precisely in the comment section of the newest song of him, D.O.A that released on 25 August 2020. This study employed discourse and sociolinguistics aspects; hence, this study's research design was a descriptive qualitative. Additionally, this study's object was a one-month comment section of Rich Brian's newest song official music video. Furthermore, there were two sources of data, primary and secondary data sources. The primary data were a comment section of Rich Brian's newest official song music video, while the secondary source was from available works of literature and urban dictionary. Therefore, to collect the data, this study did the documentation from the D.O.A. official music video from one-month duration comments. As the data obtained, there were 49 slang words found. Then, they were analyzed through Yule (2010)'s theory as the basis of word formation process standard, while Zhou \& Fan (2013)'s theory was used as the basis of word formation function standard. Data analysis is divided into several steps: reading, collecting, classifying, and analyzing the data. The result showed that derivation was the highest frequency of the word-formation process. It was $22 \%$, the acronym was $18 \%$, coinage was $16 \%$, the conversion was $14 \%$, blending was $12 \%$, compounding was $8 \%$, clipping was $6 \%$, borrowing and multiple processes were $2 \%$ of each. Besides, the highest social function was to express emotive feeling with $49 \%$ quantity of the frequency. The second higher was to pursue self-identity, achieving politeness was $8 \%$. This study suggested a more in-depth analysis of non-standard languages, such as swear words or taboo words and emoticon that can be done through a social semiotic approach.
\end{abstract}

Keywords: Slang words; word formation process; function.

\section{INTRODUCTION}

Language plays a vital role in connecting people since it is used to share feelings, ideas, and thoughts. In line with Yule (2014), He explained that language is a set of symbols that is used to communicate. The communication can run 
Mutiah, S. D., Hidayat, D. N., \& Alek, A. (2021). Exploring the word formation process on Rich Brian's official music video comments. EduLite: Journal of English Education, Literature, and Culture, 6 (1), 198-212. http://dx.doi.org/10.30659/e.6.1.198-212

smoothly where the message is conveyed well. It makes the language users aware that effective language should be used to do communication properly. However, Pilipei et al. (2014) stated that formal and standard language could not guarantee whether the message delivered is meaningful or not. As well as, Stochl (2019) believed that the use of proper English often fails due to the cultural role which has changed the role of the proper English language. It showed that culture has a role in someone and the community's language standard. In the same vein as Stochl, Vitalijivna Senior \& Yurijivna (2020) explained that the linguistics aspect has several standards in every community. One variation of them is slang words.

Slang language is an out of standard language in its form. Yet, it tends to create new vocabularies or phrases that caused extended meaning which still follow the original word that belong to some particular groups (Haspo \& Rosa, 2018). Additionally, the process of generating new words for new use is called the process of word-formation, in line with Yule (2016) that classified the wordformation process into ten forms. They are Coinage, Conversion, Clipping, Blending, Backformation, Borrowing, Compounding, Acronym, Derivation, and Multiple Process. Furthermore, many people use slang words based on their purpose and condition. Likewise, Zhou \& Fan (2013) defined some functions of using slang words to express emotive feeling, pursue self-identity, and achieve politeness. Additionally, slang words in society create solidarity and closeness in a particular community (Allan $\&$ Burridge, 2006). Therefore, slang words may have become the young community's daily language. Slang words existed in direct communication and existed in several teenagers' activities such as novels, movies, and songs (Hidayat \& Mu'man, 2020).

Talking about rap songs, it has a significant influence in American music (Risso, 2016). Rich Brian is an Indonesian rapper who has begun his debut in his fifteen years old. Moreover, his rap songs have been analyzed in linguistics, which automatically showed that his songs were exciting and challenging in their linguistics aspects, especially the word-formation. Recently, his newest single was released under title D.O.A. Further information about his newest official music video, its concept was unique due to the Honda Civic driven by him in a long journey from the desert until the cold mountain. In contrast, other singer' previous music videos in the same genre used some luxurious cars. It invited various reactions, especially when 88 Rising Youtube Channel published it officially. Those varied reactions happened because the viewers have come from various classes, groups, and communities. Moreover, Ariffin \& Tiun,(2020) found that social media texts were challenging due to their users' language creativity in engaging their followers.

Therefore, this study used Youtube as an instrument of the study since Westenberg (2016) defined YouTube as a platform for sharing videos where the viewers can freely leave the comment. Besides, several beliefs are taken into consideration for choosing Youtube comment section. A belief that described Youtube comment section is a form of interaction among the Youtube users and a form of response and reaction of content, story, and video posted by the uploader (Benson, 2015). Youtube comments interaction has three types of different interactions. First, it is a communication between the speaker and the hearers in the video. The communication between the senders (video's uploaders) and the video's recipient (viewers) is the second. Lastly, an 
interaction among the video recipients (viewers) (Herring \& Chae, 2021).

Furthermore, Yu et al. (2020) believed that comment section in an online platform could result in profound and even sensitive topic because face to face interaction tends to avoid more profound and debatable interactions. It can be said that the commenters could post Youtube comments as a personal reaction and general interaction with various attitudes, beliefs, and interest of the object being discussed within it. Above all, this study would analyze the wordformation process on the reactions' comment of D.O.A official music video and its function due to the more in-depth and more explicit comment analysis as this study's objective.

\section{Morphology}

Morphology is a linguistic term member that is also a subdiscipline of grammar that focuses on the words' structure and morpheme relationship. Furthermore, Yule, (2010) defined that morphology is an investigation of the word base. Likewise, O'Grady et al. (1996) defined it as the study of word categories and rules involved in word-formation. In short, morphology is a study of the basic word and its formation.

\section{Sociolinguistics}

Sociolinguistics is a study of the language used in society as well as Yule (2016). He defined sociolinguistics as the relationship between language and society study, which also connected linguistics interaction and the culture with the sociology aspect. Additionally, cultural interaction promotes and invites playful new expressions, vocabularies, or even omits the existing one (Allan \& Burridge, 2006). Therefore, sociolinguistics become a discipline of language that is connected with the society concerning cultural existence. Besides, language can be changed in its form and function in this term of sociolinguistics.

\section{Slang word}

A slang word is out of a common word that is used in an informal situation. It is used as the marker of a specific group of people (Allan \& Burridge, 2006). Besides, Auliana et al., (2020) defined slang words as new words created by society with old or even new extended meanings. The new word creation would happen through several specific processes, such as affixation, blending, and compounding words regarding the word-formation process. Moreover, Laksana and Boyce (2020) defined the word-formation process as a process where the word changed out of its standard. However, some certain group of people accepts it. Yule, (2010) supported this. He defined the word-formation process as creating a new word with symbolic meaning from the old word form to the new one. Moreover, he classified it into several types. Those are:

\section{Coinage}

Coinage is the invention of new words that usually take a brand's name as a common word. Additionally, Wahyu (2020) defined the coinage as the new word and existing word taking from a brand such as Beat, Toyota, and Vaseline. In the same vein as him, Yule (2010) stated that coinage was an entirely new form of words that used the commercial product as its standard. Besides, it does not employ capital letters for any commercial product such as aspirin, zipper. 
Mutiah, S. D., Hidayat, D. N., \& Alek, A. (2021). Exploring the word formation process on Rich Brian's official music video comments. EduLite: Journal of English Education, Literature, and Culture, 6 (1), 198-212. http://dx.doi.org/10.30659/e.6.1.198-212

\section{Borrowing}

Borrowing is a process of taking a word of other languages to become a common word. Laksana and Boyce (2020) stated that English adopted many words as their borrowing words. There is an immediate translation of the words borrowed in its process-for example, Chow (Chinese food), Piano (Italian), tycoon (Japan). Likewise, Yule (2010) defined borrowing as a particular type known as loan translation or calque. The natural word elements translation such as gratte-ciel as French means English scrape-sky', wolkenkrabber ('cloud scratcher') from Dutch and Wolkenkratzer ('cloud scraper') as German term. Next, all of them calques for the English language as Skyscraper.

\section{Compounding}

Compounding is connecting two separate words into a single word as like as Wahyu (2020) explained the Yules' theory that there are three kinds of compound words. First, Noun form compounding, such as, Macbook, fingerprint. Second, adjective compounding such as, low-profile, good-looking. Third, the combination of Adjective and noun, such as, Fast-food.

\section{Blending}

Yule (2010) defined blending as an activity of mixing two separate words into a single word, taking the beginning from the first word and putting the last of the second word. Example: Shoulda (Should have) You'll (You will) Smaze (smoke + haze) and Smurk (smoke + murk) also Brunch (Breakfast + Lunch)

\section{Clipping}

The reduction of one or more syllable words to be in a shorter form called clipping. For instance, gas (gasoline), cause (because), Till (Until), Darlin (darling), Fan (Fanatic). Additionally, this reduction has one type that becomes Australian and British English favorite called hypocorism when the addition of $\mathrm{y}$ and ie occurred at the end of long word reduction such as Aussie (Australian), Telly (Television), Hankie (Handkerchief) (Yule, 2010).

\section{Backformation}

The reduction process changes the function of the words that first have a role as a type and change into another type. Here are some examples, Donate as a verb (Donation as a noun), Emote as a verb (Emotion as a noun), Babysit as a verb (Baby sitter as a noun), Beautify as a verb (Beautiful as Adjective).

\section{Conversion}

This word-formation process happened when there was no reduction in the word. However, the function of the word changed, and it is acceptable. For an example of some nouns Chair, Butter, Google that could be used as a verb "someone has to chair the agenda," "we can google it anytime," "have you buttered the toast?", print out "a print out" stand up "standup comedian", crazy ideas "a crazy as a noun". 


\section{Acronym}

Acronym is the use of an initial letter of the words where its pronunciation was not only based on the letter involved such as CD (Compact Disc), BFF (Best Friend Forever), VCR (Video Cassette Recorder), ATM (Automatic Teller Machine) but also based on all letter within it that create one new word pronunciation completely such as UNESCO, NATO, PIN.

\section{Derivation}

An addition of a word, whether it has happened at the beginning (prefix) or the ending (suffix) of a word, changes the word's function. Besides, these wordformation types are largely dominated by small "bit" called affix. For example, un-, mis-, pre-, -ful, -less, -ish, -ism, and -ness which appear in words like unable, misleading, prejudge, faithful, useless, brownish, capitalism, happiness.

\section{Multiple processes}

The word-formation process of more than one process. Such as, "this project have snowballed" (compounding + conversion).

\section{The social function of slang words}

Since slang is categorized as an informal language used among society, it indicates that social factors that emerge can cause the people language variation in their communication. Adi and Azmi (2018) explained that social factors that influence society or group communication are social dimensions. It is an indicator that initially reflects the purpose, manner, topic, and mood of language. Besides, the social dimension cannot be separated from the social function. Therefore, it is clear that slang words' social function is also described the purpose of slang words used by the user. In line with it, Harared and Iriyansah (2019) found that the slang word's social function became the reason for slang user convey the slang word. Besides, Harared (2018) explains that slang word's social function is vital since it provokes strong emotion among the groups regarding their closeness and encourages hostility for those who do not share the same slang. In other words, many online communications flow deeper and more expressive because it is frequently done in a group with the same interest. However, misunderstanding and miscommunication in the social media interaction can happen if the excluded group or other interest cannot accept the social function.

Additionally, the social function is defined as the reason and reflection of why the speaker chooses and uses slang words. Likewise, Partridge (1979) classified the social function of slang word usage. Those are: to show waggishness, to share ingenuity, to be novel, to be beautiful, to avoid mistakable arresting, to be brief, to enrich the language, to cut the air of solidity, to reduce the excessive seriousness, to entertain the superior public, to ease social intercourse, to create intimacy, to show specific school's interest, also to exclude some people from particular group or interest, and to be hidden or secret from people who do not share the same interest. Furthermore, Zhou and Fan (2013) also classified the function of slang word usage into three functions. Firstly, to pursuit of self-identity, it is suggested that the slang language users have different social and professional slang, so they used it to emphasize their 
Mutiah, S. D., Hidayat, D. N., \& Alek, A. (2021). Exploring the word formation process on Rich Brian's official music video comments. EduLite: Journal of English Education, Literature, and Culture, 6 (1), 198-212. http://dx.doi.org/10.30659/e.6.1.198-212

identity. Second, to express emotive feeling means the users attempted to gain the audience's emotional status to solve the panic or nervousness of under stress situation. In other words, it is basically to emphasize the need to express emotion psychologically. Third, achieving politeness where the slang users' objectives are to create a specific atmosphere and maintain social contact. In other words, its purpose is to run the conversation smoothly. These functions were to show the speaker or writer's attitude or response to something and the speaker's purpose to show their values and classes to others. Above all, Zhou and Fan (2013) 's social function theory is considerably taken into this study because of the upgraded year and the simplicity of the classification.

\section{Previous relevant studies}

Since the word-formation is believed to have a relationship with slang words. So, there were many research studies that have been done, which automatically contribute several guidelines to this study. Some previous research studies about the word-formation process have been done in social media interaction use. Fattaut (2020) found that BTS fans used slang language for only their community; they use slang in a BTS community on the twitter interactions. Next, Hidayat and Mu'man (2020) revealed the word-formation of slang words are dominated by clipping, multiple processes, and acronym on Rich Brian song. Also, Wahyu (2020) revealed that Acronym and Blending form dominated the YouTube comments on Rich Brian. Furthermore, Ariffin and Tiun (2020) found that Malay social media interaction employed slang words that were mostly dominated by an acronym. Additionally, Pratama and Imperiani (2020) found that the Indonesian Kas-Kus website employed blending and clipping most because of the shorting words trend. Likewise, Ratnasari et al.'s (2019) study found that declarative statement of speech function is prevalent to give information to the readers. Those previous studies have done with the same aspect analyzed. However, the result provided some different new information for the word-formation process. Additionally, only one of them analyzed every word formation function in a mention interaction of Twitter. Therefore, this study would analyze the word-formation process and the social function either on 88 Rising Youtube channel, especially on the official music video of Rich Brian. Since the word-formation's social function has not been explored yet, this study proposed to add more information for word formation and its social function, which automatically described why the slang user chose certain words.

\section{METHOD}

\section{Research design and data}

This present study is categorized as discourse research. Brandmayr (2020) claimed that discourse research used to analyze group interaction where structure, condition framework, and power relation influence it. This study used the social concept more profound as slang language is identified as varied and different among languages. Besides, this study used a descriptive qualitative design where the data was taken from Rich Brian's official newest music video comment section. The total data in this study was 9.811 comments. This study took the one-month duration of Rich Brian's D.O.A official music video Youtube's comment section to be more in-depth and specific in analyzing them, 
Edulite Journal of English Education, Literature, and Culture

Vol. 6, No. 1, February 2021, pp. 198-212

more precisely the comments section on September 2020.

\section{Research instrument}

The second source of data was the related literature and the urban dictionary since the slang words should be consulted through it. This is supported by Viljanen and Are (2019), who claimed that the urban dictionary effectively found the word variation. Therefore, this study used the documentation technique due to the YouTube's comment section could be taken through it.

\section{Data analysis procedures}

The data were analyzed through several steps. Those are read the overall data obtained. Next, classify the data categorized as slang language by consulting the words through the urban dictionary. After that, collect them based on the slang word categories. Lastly, define and decide the function of them after relating some related context of the words found. The word-formation process data analyzed through Yule's (2010) theory, while their function were analyzed through Zhou and Fan (2013)'s theory.

\section{RESULT AND DISCUSSION}

This study's primary objectives were the slang word-formation process and its social functions on the comment section of Rich Brian's official music video's newest song. The result of them would be described as Table 1.

\section{The word formation processes}

Table 1. Slang word formation process result

\begin{tabular}{|c|c|c|c|c|}
\hline No & Word Formations & Data & Quantity & Percentage \\
\hline 1 & Coinage & $\begin{array}{l}\text { Honda Civic, Yoda, Minecraft, } \\
\text { Civic, Grand Turismo 7, Maserati, } \\
\text { Indonesian, Shout East Asia }\end{array}$ & 8 & $16 \%$ \\
\hline 2 & Borrowing & Du'a & 1 & $2 \%$ \\
\hline 3 & Compounding & $\begin{array}{l}\text { Bodykit, Overproud, upbeat, } \\
\text { roadtrip }\end{array}$ & 4 & $8 \%$ \\
\hline 4 & Blending & $\begin{array}{l}\text { Hasn't, Ain't, I'd, SoCal, didn't, } \\
\text { gonna }\end{array}$ & 6 & $12 \%$ \\
\hline 5 & Clipping & ass, tho, nuff & 3 & $6 \%$ \\
\hline 6 & Conversion & $\begin{array}{l}\text { The weekday, weekend, } \\
\text { Microwaving, flex, youtube, dope, } \\
\text { cap }\end{array}$ & 7 & $14 \%$ \\
\hline 7 & Acronym & $\begin{array}{l}\text { LMAO, LOL, MV, KPOP, OMG, } \\
\text { POV, JDM, FAME, PLZ }\end{array}$ & 9 & $18 \%$ \\
\hline 8 & Derivation & $\begin{array}{l}\text { Uncomfortable, oddly unsetting, } \\
\text { better, heavily, sober, singer, } \\
\text { rapper, artist, musician, } \\
\text { protagonist, energizing }\end{array}$ & 11 & $22 \%$ \\
\hline 9 & Multiple process & Asian. Microwaving & 1 & $2 \%$ \\
\hline 10 & Coinage & Du'a & 50 & $100 \%$ \\
\hline & & TOTAL & 8 & $16 \%$ \\
\hline
\end{tabular}

According to the word-formation process, it showed that there were 45 comments which contained 50 slang words within it. Derivation became mostly used since it reaches $22 \%$ in 11 times frequencies. Besides, the acronym was the second higher frequency, with $18 \%$ of the comment section. At the same frequency, coinage also had $18 \%$ used in that music video comment. 
Mutiah, S. D., Hidayat, D. N., \& Alek, A. (2021). Exploring the word formation process on Rich Brian's official music video comments. EduLite: Journal of English Education, Literature, and Culture, 6 (1), 198-212. http://dx.doi.org/10.30659/e.6.1.198-212

Furthermore, borrowing became the lowest frequency used of slang, only $2 \%$ in only one frequency. Besides, conversion obtained 14\%, clipping 6\%, blending $12 \%$, and compounding $8 \%$. Furthermore, the social function of the slang words result would be described as below:

\section{The social Functions}

Table 2. Slang word social function

\begin{tabular}{clll}
\hline No & Social Function & Quantity & Percentage \\
\hline 1 & Pursuit Self-identity & 19 & $39 \%$ \\
\hline 2 & Express Emotive Feeling & 24 & $49 \%$ \\
\hline 3 & Achieve Politeness & 4 & $8 \%$ \\
\hline 4 & Multiple Functions & 2 & $4 \%$ \\
\hline Total & & 49 & 100 \\
\hline
\end{tabular}

The social function used on the slang words that existed in the comment section was 49 because, from 50 comments, there is a comment that has two slang words. The result revealed that the most used function was to express the emotive feeling with $51 \%$ and 25 used frequencies. Besides, pursuit self-identity was the second higher frequency with $41 \%$ and 20 frequencies used. The last social function was achieving politeness with $4 \%$ usage frequencies.

\section{The word formations and social function}

The research questions of this study are the slang word-formation process and its social function. The results showed that the slang words that existed in the comment section is dominated by derivation form. Unlike the study of Laksana $\&$ Boyce (2020), they found that borrowing and clipping form were the most frequently used in the WhatsApp group conversation. This study found that derivation, acronym, and coinage become the domination of slang wordformation. However, Wahyu (2020) found that clipping became the most used on Rich Brian Youtube channel comment section. Although some identifiable aspects were analyzed there and the research time was near with this study, this study result of slang word-formation was different. It is caused by the rapid change of slang popularity in society. Eble (1996) explained that slang is a temporary word of society, so its popularity changed quickly. Next, this study has derivation $(22 \%)$ as the highest used, indicating the user tends to modify the word creatively. The words "sober" "Asian" "singer" tend to express the noun form which purpose of using them was to address Rich Brian as the performer or even the subject of their perception. Eble (1996) supports this by stating that the teenager's derivation in general vocabularies becomes the attachment of noun-adjective and repetition indicator. 
Edulite Journal of English Education, Literature, and Culture

Vol. 6, No. 1, February 2021, pp. 198-212

E-ISSN: 2528-4479, P-ISSN: 2477-5304

http://jurnal.unissula.ac.id/index.php/edulite DOI: http://dx.doi.org/10.30659/e.6.1.198-212

Table 3. Derivation and multiple process word formation

\begin{tabular}{|c|c|c|}
\hline Sentences & Word Formations & Functions \\
\hline $\begin{array}{l}\text { 1. "This is basically } \\
\text { Blinding Lights but } \\
\text { they guy was Asian }\end{array}$ & $\begin{array}{l}\text { Basic+ally } \\
\text { Asia+n } \\
\text { Sober }\end{array}$ & $\begin{array}{l}\text { 1.Pursuing self-identity \& To express } \\
\text { emotive feeling. }\end{array}$ \\
\hline $\begin{array}{l}\text { 2. I see it and it makes me } \\
\text { uncomfortable }\end{array}$ & Un+comfort+able & 2.To express emotive feeling. \\
\hline
\end{tabular}

The comment number one implied a double social function. First, to express emotive feeling about Rich Brian. It described that Rich Brian has copied the song and the music video concept of "Blinding Light." It is also categorized as pursuing self-identity because he asserts his knowledge and interest in that music genre (Weekday the singer of blinding light). His comment would be understood and responded to by only those who familiar with Blinding Light. Sahardin et al. (2020) argued that slang words become a part of sociolinguistics that result from several specific communities' social contexts. Besides, uncomfortable was processed as derivation since its formation at the beginning (prefix) and ending (suffix). The function is to express emotive feeling where the slang user shows his/her feeling by saying that "uncomfortable."

Next, acronym was found in high frequency (18\%). It revealed that many social media societies tend to use acronym since it is shorter and more effective in smoothing the conversation. Besides, Pratama and Imperiani (2020) found that a shorter form of words is needed in using social media to engage with the reader of the message. Additionally, Izazi and Tengku-Sepora (2020) found that the slang user on the internet attempted to convey their message quickly and shortly due to their quick typing time that expects the responses and replies from the people in that online conversation. In short, a shorter form of the original form of language is highly used, especially in social media.

Table 4. Acronym word-formation function

\begin{tabular}{lll}
\hline \multicolumn{1}{c}{ Sentences } & \multicolumn{1}{c}{ Word Formations } & \multicolumn{2}{c}{ Function } \\
\hline $\begin{array}{l}\text { "lmao he's come so far, } i \\
\text { love it" "Brian: Sorry bro, }\end{array}$ & $\begin{array}{l}\text { Laughing my ass off } \\
\text { Japanese Domestic } \\
\text { I'm a JDM guy" }\end{array}$ & $\begin{array}{l}\text { To express emotive } \\
\text { feeling \& Pursuit self- } \\
\text { identity }\end{array}$ \\
$\begin{array}{l}\text { "and will get suspended } \\
\text { soon lol" }\end{array}$ & Laugh out loud & 2.To express emotive feeling. \\
\hline
\end{tabular}

These acronym samples are described in the shorter form, which only takes the word's beginning letter to become a word. However, they have a different function because we need to appropriate the slang usage with the context (Allan \& Burridge, 2006). In that sentence, the LMAO has an emotive feeling when the slang user tends to be surprised by Rich Brian's music video's progress. Moreover, the addition of "I love it" makes it has a clear function. Besides, JDM guy is the Japanese Domestic Market, which here the user attempt to share his knowledge and interest in the specific field of market precisely Japanese market. As a result, it would be understood by those who shared the same knowledge about it. Moreover, the word lol, laugh out loud, has emotive feeling 
Mutiah, S. D., Hidayat, D. N., \& Alek, A. (2021). Exploring the word formation process on Rich Brian's official music video comments. EduLite: Journal of English Education, Literature, and Culture, 6 (1), 198-212. http://dx.doi.org/10.30659/e.6.1.198-212

function but with different feelings of hate because the slang user attempted to wish that Rich Brian Music Video be cut soon. This is supported by Aikhenvald and Storch (2019), who found that the slang becomes the youth creativity of language that deices and meaning are also a prerogative. It means although the word lol or ROTFL describe the comfortable nuance, the meaning can be different. It is based on the users' intention. The next high category is coinage $(16 \%)$.

Table 5. Coinage word formation and function

\begin{tabular}{lcc}
\hline \multicolumn{1}{c}{ Sentences } & Word Formations & Functions \\
\hline $\begin{array}{l}\text { This guy started from } \\
\text { microwaving a bread to this, } \\
\text { wow }\end{array}$ & Microwave-ing & To pursue self-identity \\
\hline $\begin{array}{l}\text { so I don't have to YouTube } \\
\text { him every time haha }\end{array}$ & You Tube & To express emotive feeling \\
\hline
\end{tabular}

These names of specific brands are also appeared in there because of those brands and some associated relation. Yule (2010) explained that coinage makes the product name become general daily words. The word Honda civic is a coinage where the user used it to express emotional feeling because he intended to show its quality since the music video showed the Honda civic, which Rich Brian surprisingly used. At the same time, another singer is believed to use a more luxurious car. In the same vein, New Grand Turismo 7 is a racing simulation video game that uses luxury and expensive cars at the race. Allan $\&$ Burridge (2006) explained that one characteristic of slang was serving a specific group recognition device that made the outer group not join that device. Hence, this comment's function is to pursue self-identity and express emotional feeling because the slang user initiates his familiarity with the certain game and associate it with the car in the music video. Simultaneously, it implies that Honda Civic has become luxurious since Rich Brian used it in his music video.

Table 6. Conversion word and the function

\begin{tabular}{ll}
\hline Sentences & Functions \\
\hline "Honda civics never break down" & To express an emotive feeling \\
"Sticking to his asian roots! Civic gang!!" & To pursuit self-identity \\
"Damn, the new Gran Turismo 7 looking & To pursuit self-identity \& to express an \\
hella great" & emotive feeling \\
\hline
\end{tabular}

The next category was conversion and multiple processes. It is $14 \%$. Mostly, the slang users in comment columns aimed to deliver their familiarities to some specific things that automatically functioned as a pursuing self-identity. It is an example of conversion that is purposively used to pursue self-identity. The slang user uses microwave that actually a noun to be a verb. This word variation happened in the comment section in line with Fajardo (2019), he claimed that slang user used lexical creativity, especially on morphology and semantics level. Semantically this comment above emphasized his knowledge about Rich Brian, whose uploaded video of microwaving a bread for 30 seconds was viral because it reached 5.154 .440 viewers although the quality of it was just very basic rather than his newest music video. In other words, the slang user tried to share that he has been following Rich Brian for a long time (from 
being not popular yet) and still following him with popularity now. Unlike Rizky (2018) research that did not find any self-identity function because the slang context in the Deadpool comic is made to attract many readers generally, whereas the comment section of Rich Brian was purposively made by those who familiar, have interest in him. Additionally, Allan \& Burridge (2006) explained that swear, taboo, jargon, and slang often become a solidarity sign among communities. Therefore, only those who know about Rich Brian microwaving video can be connected with the context. Besides, Youtube's use, which lexically changed from noun to be verb showed that the user wants to share her emotive feeling because it is implied that she always watches Rich Brian's music video through Youtube. Additionally, she adds "every time" to emphasize her frequencies of watching it. In other words, conversing the word has a meaning to emphasize the emotional feeling and secret knowledge that can be known by several people in a specific community.

The next slang word is blending which has $12 \%$ users.

Table 7 . Blending and the function

\begin{tabular}{lll}
\hline Sentences & Word Formations & Functions \\
\hline $\begin{array}{l}\text { If you live in SoCal "I am in } \\
\text { the } 818 \text { don't take no breaks" } \\
\text { hits different }\end{array}$ & SoCal = South of California & To pursuit self-identity \\
\hline $\begin{array}{l}\text { I DIDN'T EXPECT SUCH A } \\
\text { AMAZING AND FUN SONG. }\end{array}$ & DIDN'T = Did not & To express an emotive feeling \\
\hline
\end{tabular}

The word SoCal has the purpose of showing the user's identity of a country. The user tends to show that South California has the main metropolitan region. Moreover, he connected the 88 rising names that create that southern California is used to know the 88 risings. In other words, he showed his pride that 88 rising (a big agency of Rich Brian) is a part of his region. This is supported by Yule (2016). He asserted that another function of showing pride is called prestige covert behind the slang words among youngsters. The users secretly wanted to show their prestige unintentionally. The word "DIDN'T" expresses more about the slang user surprise towards the music video quality and concept. Additionally, using capital letters attempted to emphasize the feeling of the user. The research of Heath (2018) found that capitalization in social media has several meanings. Those are anger, emotive, and emphatic that the reader can indirectly imagine the intonation of the users. In short, the user uses the capital letter to emphasize his message within the emotional feeling.

Table 8. Compounding and borrowing followed by the functions

\begin{tabular}{|c|c|c|}
\hline Sentences & Word Formations & Functions \\
\hline $\begin{array}{l}\text { Man, I don't know why, but } \\
\text { this is my new roadtrip song }\end{array}$ & Road trip & $\begin{array}{l}\text { To express emotive feeling }+ \\
\text { to achieve politeness }\end{array}$ \\
\hline $\begin{array}{l}\text { Du'a is pray basically in } \\
\text { South East Asia }\end{array}$ & Du’a : آلأدَعَاءُ Arabic & To pursue self-identity \\
\hline
\end{tabular}

The user's compound road and trip become a word that shows his activity of going somewhere while the appearance of "my new song" expresses his emotive feeling about the song recently became the users' favorite playlist to reduce the boredom during users' trip. Primasari et al. (2020) found that out of 
Mutiah, S. D., Hidayat, D. N., \& Alek, A. (2021). Exploring the word formation process on Rich Brian's official music video comments. EduLite: Journal of English Education, Literature, and Culture, 6 (1), 198-212. http://dx.doi.org/10.30659/e.6.1.198-212

standard word also tend to show several functions. One of them is pride meaning. Additional evidence, the use of "Man" in that comment also showed the pride to Rich Brian besides its function to achieve politeness (Fitriah \& Hidayat, 2018). Allan and Burridge (2006) state that the use of "man, bro" tends to have a function that shows to address the hearer; however, it can have multiple functions to suggest a relaxed conversation. Above all, it showed man's use, and brother emphasizes the emotive feeling of slang user with politeness and indicates the relaxed and intimate reaction.

The borrowing of "Du'a" comes from the title of the song "D.O.A" It is an acronym of Dead On Arrival, which urban dictionary defined it as a death that comes before it gets where it should go. On the other hand, some of them presumed that doa is an activity that is so-called pray. Therefore, this comment explains that doa is borrowed from Arabic language that is written non in Arabic orthography. The music video's title makes the viewers judged that the title is deliberately present to be a click-bait. The study of Zhang and Clough (2020) explored click-bait in social media results in misleading information. It makes the right information is needed in fixing the misleading.

Therefore, the information implied a self-identity as a Muslim was done to clarify the misleading of D.O.A itself. In short, borrowing the Arabic word in his official music video has attracted the viewers to watch it while most of the comment section was filled with some people who know the "doa" in their community's knowledge without knowing about the acronym of dead on arrival. Hence, only showing identity can clarify the meaning of it.

Above all, the analysis of word-formations and the social function automatically implied the slang users' reasons to use those words. It automatically showed their identity, knowledge of something not general, closeness, appreciation, and even hatred of someone or something. Besides, the tone or feeling stressed on the message through social media can be identified if we recognized and able to identify the function of them. Therefore, slang language has no permanent meaning or new due to rapidly changing language in every community.

\section{The implication of language teaching and learning}

The language ideology should have a place wherever everyone goes. The ideology within him or she would go with them. As a teacher involved in teenage activities in school and their social interaction, the teacher should be aware that diversity also happens in language. Razfar et al. (2020) explained that urban schools in America should deal with culturally responsive education because the convoluted language in urban schools was overwhelmed. In other words, cultural awareness in education is needed to make all the school stratum can explore their language. Moreover, the teacher also has an important role in facing it. Moreover, Suryaman and Juharyanto (2020) stated that teachers took part in integrating multicultural values. It is done in the lesson plans preparation and its implementation, aiming to raise the respect of diversity systematically. Besides, make the students aware that their language should understand a clear message conveyed through the systematic lexical and various word-formation. Additionally, it also makes them have critical thinking, especially in reading, writing and responding to others on social media. 


\section{CONCLUSION}

Above all the findings analysis discussions, this study highlighted some points that became the conclusion of this study. First, the use of derivation $(22 \%)$ and acronym (18\%), the coinage was (16\%), the conversion was $(14 \%)$, the blending was $(12 \%)$, the compounding was $(8 \%)$, and the borrowing and multipleprocesses were at the same percentage $(2 \%)$ of each. The function of them were dominated by to express emotive feeling (49\%), Pursuit self-identity was (39\%) and $8 \%$ for achieving politeness and $2 \%$ for the multiple functions.

The slang words in society are contemporary, which means it can last longer or even lost with no fixed duration. Second, the slang user used them to emphasize, express, inform, appreciate, and even humiliate as something or someone's responses. Third, the commenters of Rich Brian D.O.A's official music video are shorter in a form (derivation and acronym were the highest). However, they still understandable and acceptable by the readers. Forth, the slang words on that official music video positively (to express emotive feeling and pursuit self-identity) tend to share the "community" language and identity.

Some limitations were found in this study; a more robust method is expected to be done in the future, so it can be more apparent to the readers to use the study as the guideline. Especially, in the Next, this study suggests the future researchers do the comment section analysis in the social media concerning the swear words, taboo words as the main focus, because this study found many swear words and taboo words that music video comments. Hence, they need to be classified and analyzed more in-depth. Besides, emoji found are also suggested to be analyzed in the future.

\section{REFERENCES}

Adi, W. T., \& Azmi, A. (2018). Slang expression in Little Man movie based on social dimension. LINGUA (Journal of Language, Literature, and Language Teaching), 15(2), 97-113. https://doi.org/10.30957/lingua.v15i2.480.2.

Aikhenvald, A. Y., \& Storch, A. (2019). Creativity in language. International Journal of Language and Culture, 6(1), 1-9. https://doi.org/10.1075/ijolc.00012.sto.

Allan, K., \& Burridge, K. (2006). Forbidden words: Taboo and the censoring of language. In Forbidden Words: Taboo and the Censoring of Language. https://doi.org/10.1017/9780511617881.

Ariffin, S. N. A. N., \& Tiun, S. (2020). Rule-based text normalization for Malay social media texts. International Journal of Advanced Computer Science and Applications, 11(10), 156-162. https://doi.org/10.14569/ijacsa.2020.0111021.

Auliana, R., Sendjaja, S. D. P. D., \& Kirana, V. N. (2020). Prevalent positioned slang word tapestry in "Potatoes Crew" whatsapp group. English Journal Literacy Utama, 5(1), 317-324.

Benson, P. (2015). Commenting to learn: Evidence of language and intercultural learning in comments on youtube videos. Language Learning and Technology, 19(3), 88-105. https://eric.ed.gov/?id=EJ1075808.

Brandmayr, M. (2020). Discourse analysis. In Analyzing group interactions: A guidebook for qualitative, quantitative and mixed methods (pp. 1-218). Routledge.

Eble, C. (1996). Slang and sociability in a group among college students. The University of North California Press. 
Mutiah, S. D., Hidayat, D. N., \& Alek, A. (2021). Exploring the word formation process on Rich Brian's official music video comments. EduLite: Journal of English Education, Literature, and Culture, 6 (1), 198-212. http://dx.doi.org/10.30659/e.6.1.198-212

Fajardo, J. A. S. (2019). Exploring the "shashification" of teenage slang. English Today, 35(3), 49-54. https://doi.org/10.1017/S0266078418000251.

Fattaut, L. (2020). An analysis of slang words used by BTS ARMY community conversation on Twitter. Undergraduate thesis. IAIN Salatiga.

Fitriah, F., \& Hidayat, D. N. (2018). Politeness: Cultural dimensions of linguistic choice. Indonesian Journal of English Education, 5(1), 26-34. http://journal.uinjkt.ac.id/index.php/ijee/article/view/2041.

Harared, N. (2018). Slang created and used in 1cak.com site: A sociolinguistics study. Humaniora, 9(2), 119-127. https://doi.org/10.21512/humaniora.v9i2.4262.

Harared, N., \& Iriyansah, M. R. (2019). Slang analysis of the conversation among drivers Gosend by Gojek: A Case Study in Whatsapp Group. Seminar Nasional Struktural 2018, 107-113. https://doi.org/10.33810/274166.

Haspo, F. C., \& Rosa, R. N. (2018). An analysis of slang word in song lyrics Eminem on Album Kamikaze. E-Journal of English Language \& Literature, 7(4), 523-529. http://ejournal.unp.ac.id/index.php/ell/article/view/101919.

Heath, M. (2018). Orthography in social media: Pragmatic and prosodic interpretations of caps lock. Proceedings of the Linguistic Society of America, 3(1), 55-68. https://doi.org/10.3765/plsa.v3i1.4350

Herring, S. C., \& Chae, S. W. (2021). Prompt-Rich CMC on YouTube: To what or to whom do comments respond? Proceedings of the 54th Hawaii International Conference on System Sciences, 2906-2915.

Hidayat, T. M., \& Mu'man, M. (2020). The word formation process of slang words in Rich Brian's song titled Dat Stick. PROJECT (Professional Journal of English Education), 3(4), 483. https://doi.org/10.22460/project.v3i4.p483-488.

Izazi, Z. Z., \& Tengku-Sepora, T. M. (2020). Slangs on social media: Variations among malay language users on twitter. Pertanika Journal of Social Sciences and Humanities, 28(1), 17-34.

Laksana, I. P. Y., \& Boyce, G. P. (2020). A morphological study in group online communication: Word-formation processes among college students in a WhatsApp group. SOSHUM: Jurnal Sosial Dan Humaniora, 10(2), 197-211. https://doi.org/10.31940/soshum.v10i2.1837.

O’Grady, W., Dobrovolsky, M., \& Katamba, F. (1996). Language: A preview. Contemporary linguistics: An introduction, ed. William O'Grady, Michael Dobrovolsky y Francis Katamba (Harlow: Addison Wesley Longman, 1997), 2.

Partridge, E. (1979). Slang: Today and yesterday. Routledge and Kegan Paul Ltd.

Pilipei, Y., \& Pyeypenko, I. (2014). Slang versus "Proper English" in the modern world. Aphn-Journal.in.Ua, 29(3), 85-89.

Pratama, I. B., \& Imperiani, E. D. A. (2020). Word Formation Processes of Slang in KasKus. Conaplin 2019, 430(2), 97-101. https://doi.org/10.2991/assehr.k.200406.019.

Primasari, D., Alek, A., Hidayat, D., \& Hadiyansyah, D. (2020). Uncovering the function of taboo words used in "Not Another Teen Movie." Proceedings of the Proceedings of the 5th International Conference on Education in Muslim Society, 1-5. https://doi.org/10.4108/eai.30-9-2019.2291135.

Ratnasari, D., Hidayat, D. N., Alek, A., \& Defianty, M. (2019). Interpersonal meaning analysis of Indonesian politicians' Instagram captions. Advances in Social Science, 
Edulite Journal of English Education, Literature, and Culture

Vol. 6, No. 1, February 2021, pp. 198-212

E-ISSN: 2528-4479, P-ISSN: 2477-5304

http://jurnal.unissula.ac.id/index.php/edulite DOI: http://dx.doi.org/10.30659/e.6.1.198-212

Education and Humanities Research, 408, 222-230.

Razfar, A., Rumenapp, J. C., \& Torres, Z. (2020). Administrating language: The language ideological voices of urban school administrators in urban education. Urban Education, 5(3), 1-29. https://doi.org/10.1177/0042085920959136.

Risso, E. (2016). Rap lyrics translation: Theoretical and practical aspects. New Voices in Translation Studies, 15, 1-30.

Rizky, E. A. (2018). The functions of slang words by the main and minor characters in Mad About Millie Vol. 1 and Deadpool Vs Old Man Logan comic books (Vol. 1). Sanatha Dharma University.

Sahardin, R., Hudiya, S., \& Samad, I. A. (2020). An investigation of word formation processes of indonesian slang words. Humanities and Social Sciences Reviews, 8(3), 209-220. https://doi.org/10.18510/hssr.2020.8322.

Stochl, L. (2020). Internet slang: Corruption of the English language. https://princemere.gordon.edu/2020/04/27/lauren-stochl-2020/.

Suryaman, S., \& Juharyanto, J. (2020). The role of teachers in implementing multicultural education values in the Curriculum 2013 implementation in Indonesia. Journal of Education and Practice, 11(3), 152-156. https://doi.org/10.7176/jep/11-3-16.

Viljanen, L., \& Are, H. T. (2019). "YOU THE REAL MVP" A Study on 10 English Slang Words and How They Are Used to Describe People on Social Media (Issue April). Tampere University.

Vitalijivna Senior, K. I., \& Yurijivna, K. A. Y. (2020). Features of slang in American rap songs lyrics language (pp. 139-141).

Wahyu, N. (2020). Word formation analysis of slang language used in comments of Rich Brian's Youtube Channel. State Institute for Islamic Studies Salatiga.

Westenberg, W. (2016). The influence of YouTubers on teenagers: A descriptive research about the role YouTubers play. University of Twente.

Yu, C. E., Wen, J., \& Yang, S. (2020). Viewpoint of suicide travel: An exploratory study on YouTube comments. Tourism Management Perspectives, 34(March), 1-8. https://doi.org/10.1016/j.tmp.2020.100669.

Yule, G. (2006). The study of language (3rd ed.). Cambridge University Press.

Yule, G. (2010). The study of language (4th ed.). Cambridge University Press.

Zhang, C., \& Clough, P. D. (2020). Investigating clickbait in Chinese social media: A study of WeChat. Online Social Networks and Media, 19(July), 1-13. https://doi.org/10.1016/j.osnem.2020.100095.

Zhou, Y., \& Fan, Y. (2013). A sociolinguistic study of American slang. Theory and Practice in Language Studies, 3(12), 2209-2213. https://doi.org/10.4304/tpls.3.12.2209-2213.

Conflict of Interest Statement: The authors declare that the research was conducted in the absence of any commercial or financial relationships that could be construed as a potential conflict of interest.

Copyright $($ C) 2021 Mutiah, Hidayat, and Alek. This is an open-access article distributed under the terms of the Creative Commons Attribution License (CC BY). The use, distribution or reproduction in other forums is permitted, provided the original author(s) and the copyright owner(s) are credited and that the original publication in this journal is cited, in accordance with accepted academic practice. No use, distribution or reproduction is permitted which does not comply with these terms. 